\title{
Synthesis and Characterization of Chirally Deuteriated sn-Glycerols
}

\author{
Yoshihiro Nishida, Hirotaka Uzawa, Shizu Hanada, \\ Hiroshi OHRui and Hiroshi Meguro* \\ Department of Food Chemistry, Faculty of Agriculture, Tohoku University, \\ Tsutsumidori-Amamiyamachi 1-1, Sendai 980, Japan \\ Received February 14, 1989
}

\begin{abstract}
$(1 S)$ - $\left[1-{ }^{2} \mathrm{H}\right]-s n$-Glycerol (1a) was obtained in three steps from $(6 S)$ - $\left[6-{ }^{2} \mathrm{H}\right]-1,6$-anhydro- $\beta$-Dgalactopyranose and converted to the $(1 R)$-isomer $(1 \mathrm{~b})$ via an $S_{\mathrm{N}} 2$ reaction of a $1-O$-methanesulfonylated derivative. The ${ }^{1} \mathrm{H}$ and ${ }^{13} \mathrm{C}$-NMR spectra well characterized their structure and stereochemistry.
\end{abstract}

Diastereoselectively deuteriated $s n$-glycerols (Schemes 1 and 2) are key compounds for biosynthetic studies of $O$-alkylated glycerolipids ${ }^{1)}$ and other natural products, ${ }^{2)}$ as well as for conformational studies ${ }^{3 \sim 7)}$ on glycerolipids by NMR spectroscopy. Recently, ${ }^{2)}$ an enzymatic method has been presented to prepare diastereoisomeric $s n$-glycerols deuteriated at the C-3 position, which were applied to biosynthetic studies of clavulanic acid. In this paper, we present the first chemical syntheses of the other two stereoisomers $\mathbf{1 a}$ and $\mathbf{1 b}$ chirally deuteriated at the $\mathrm{C}-1$ position, and characterize their structures with ${ }^{1} \mathrm{H}$ and ${ }^{13} \mathrm{C}$ NMR spectroscopy. ${ }^{8)}$

\section{Results and Discussion}

a) Syntheses of chirally deuteriated snglycerols (1a and $\mathbf{1 b}$ )

In our previous studies, ${ }^{9 \sim 11)}$ a general synthetic method for $(6 S)-\left(6-{ }^{2} H\right)$-D-hexoses was developed (Scheme 1). The method involved two key reactions: photobromination of the 1,6-anhydro- $\beta$-D-hexopyranose derivatives (I) to give the C-6 exo bromides (II), and a subsequent deuteride reduction to afford the $(6 S)$-deuteriated compounds (III). In the present study, the intermediate 1,6-anhydrosugar (III) was successfully used to prepare $s n$ glycerols chirally deuteriated at C-1 (1a and
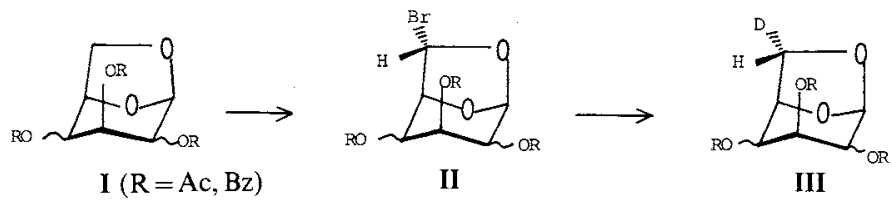

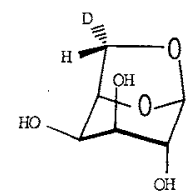

2

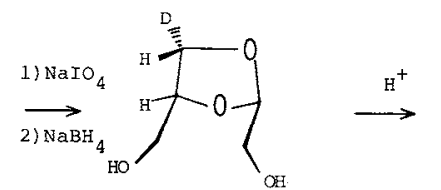

3

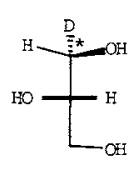

$1 \mathbf{a}$

Scheme 1.

* To whom correspondence should be addressed. 


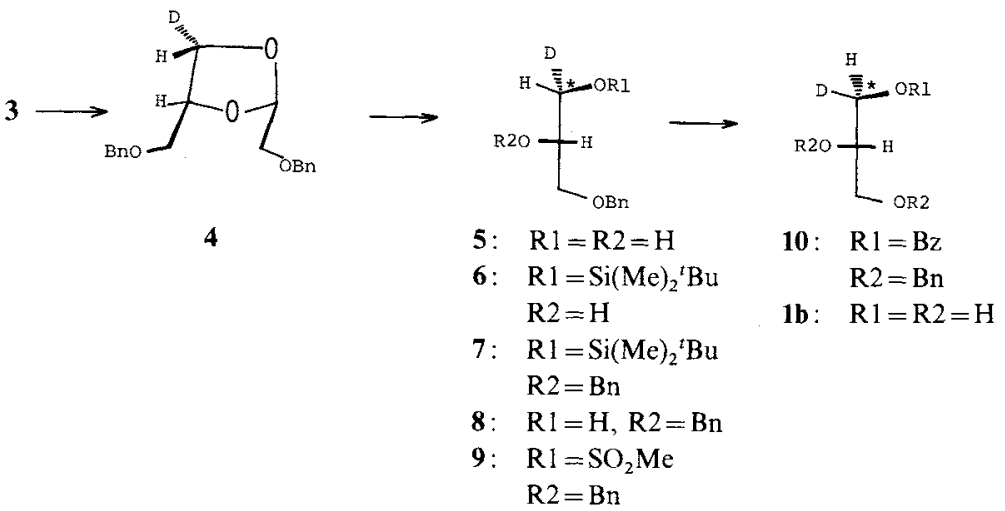

Scheme 2.
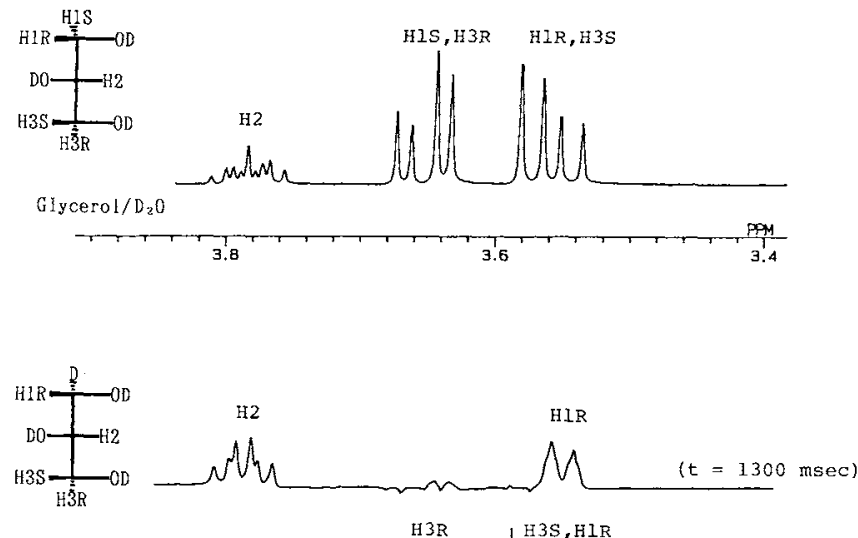

(IS) $-\left[1-{ }^{2} H\right]-$ sn-Glycerol

$1 \mathbf{a}$ wh U.
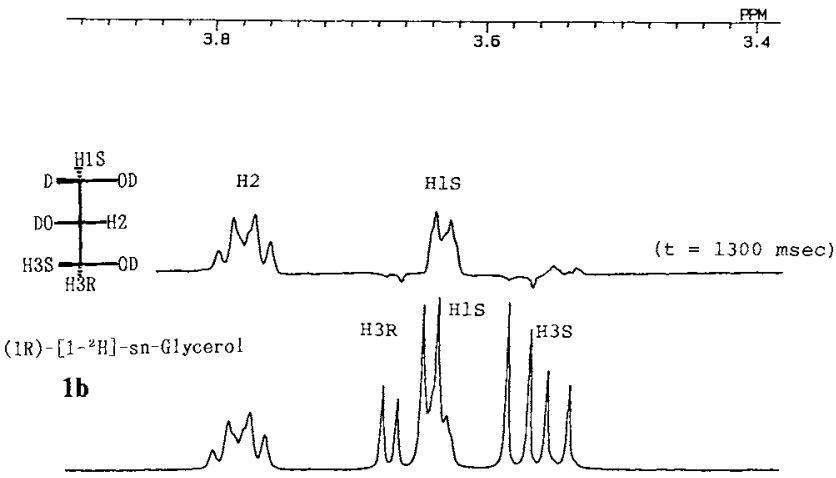

Fig. 1. $400 \mathrm{MHz}{ }^{1} \mathrm{H}-\mathrm{NMR}$ Spectra of Glycerol, $\mathbf{l a}$ and $\mathbf{1 b}$ in $\mathrm{D}_{2} \mathrm{O}$.

For $1 \mathrm{a}$ and $\mathbf{1 b}$, partially relaxed spectra using the inversion recovery method with a $180-t-90$ pulse sequence are also shown.

1b).

$(6 S)$-Deuteriated 1,6-anhydro- $\beta$-D-galactopyranose (2), which had already been synthe- sized in our preceding studies, ${ }^{10,11)}$ could be converted into $\mathbf{1 a}$ with facility by oxidative cleavage with $\mathrm{NaIO}_{4}$ (room temperature, 30 
min), and subsequent $\mathrm{NaBH}_{4}$ reduction and acid hydrolysis with $60 \% \mathrm{CF}_{3} \mathrm{COOH}$. The total yield from 2 was ca. $60 \%$. The use of a Dglucose isomer ${ }^{9)}$ instead of 2 was also successful, but took a longer time to complete the $\mathrm{NaIO}_{4}$ oxidation (room temperature, $\mathrm{ca} .3 \mathrm{hr}$ ).

The conversion of the $(2 S)$-isomer (1a) into the $(1 R)$-isomer $(\mathbf{1} \mathbf{b})$ was accomplished via an $S_{\mathrm{N}^{2}}$ reaction of 1-O-methanesulfonylated compound 9 with sodium benzoate (Scheme 2). Substrate 9 was prepared from 3 by the following sequence of reactions: benzylation (benzyl bromide and sodium hydride in dimethylformamide), acid hydrolysis $(60 \%$ aqueous trifluoroacetic acid at $60^{\circ} \mathrm{C}$, selective silylation at a primary hydroxyl group ('butyldimethylsilyl chloride, triethylamine and 4- $\mathrm{N}, \mathrm{N}$-dimethylamino pyridine in $\mathrm{CH}_{2} \mathrm{Cl}_{2}$ ), benzylation at $\mathrm{OH}-2$, desilylation (tetra- $n$ butylammonium fluoride), and methanesulfonylation (methanesulfonyl chloride in pyridine). The $S_{\mathrm{N}} 2$ reaction of 9 with sodium benzoate (in dimethylformamide at $120^{\circ} \mathrm{C}$ for $6 \mathrm{hr}$ ) gave $\mathbf{1 0}$ in a $\mathrm{ca} .90 \%$ yield, which was debenzoylated in sodium methoxide in methanol and debenzylated by hydrogenolysis with palladium black in methanol to give the desired $\mathbf{1 b}$.

\section{b) ${ }^{1} H$ and ${ }^{13} C-N M R$ characterization of $\mathbf{1 a}$ and $\mathbf{1 b}$.}

Although diastereoselectively deuteriated $s n$-glycerols have already been prepared enzymatically, ${ }^{2)}$ the spectrometric behavior to characterize each of the diastereoisomers have not yet been reported. Moreover, the absolute stereochemistry induced by the enzymatic reactions seemed to be difficult to determine. In our diastereoselective syntheses, as has just been shown, the absolute stereochemistry in 1a and $\mathbf{1 b}$ was already established at C-5 and C-6 in starting compound 2 . Here, ${ }^{1} \mathrm{H}-\mathrm{NMR}$ spectra of $1 \mathbf{a}$ and $\mathbf{1 b}$ in $\mathrm{D}_{2} \mathrm{O}$ were successfully used to characterize their stereochemical structures

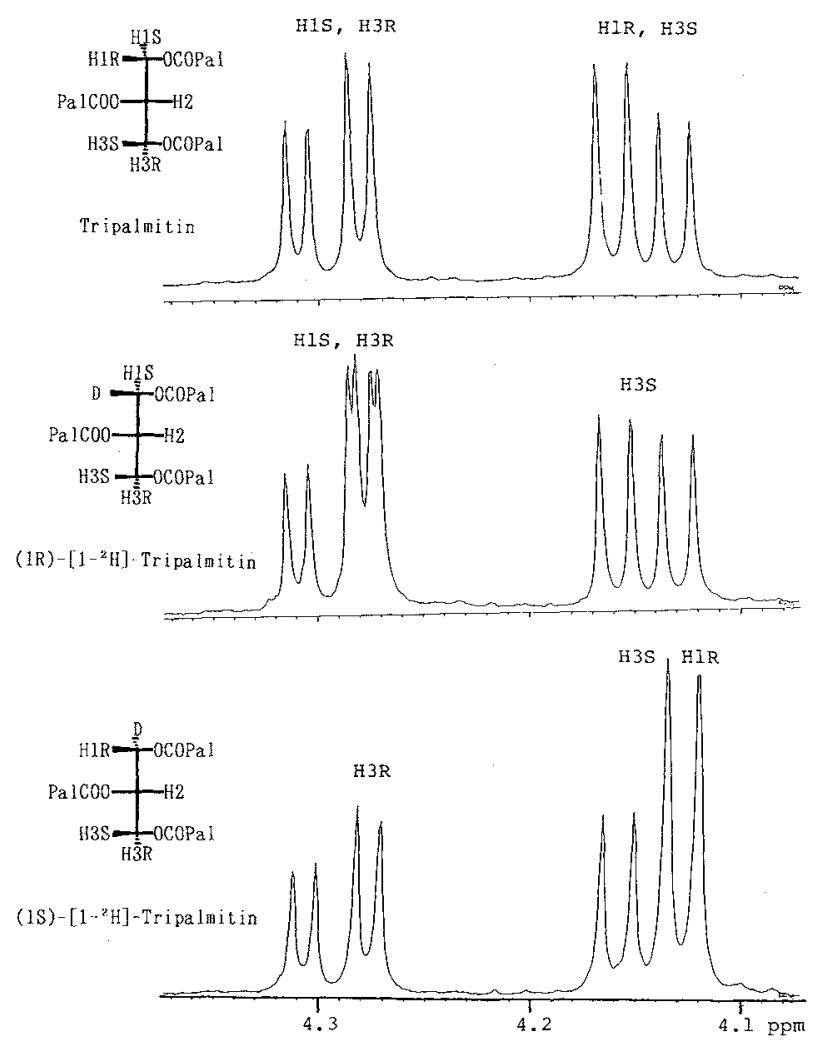

Fig. 2. $400 \mathrm{MHz}{ }^{1} \mathrm{H}-\mathrm{NMR}$ Spectra of Tripalmitin and Its $(1 S)$ - and (1R)-Deuteriated Analogues in $\mathrm{CDCl}_{3}$. 
(Fig. 1). The ${ }^{1} \mathrm{H}-\mathrm{NMR}$ spectrum of $\mathbf{1}$ a showed that one proton signal at $\delta 3.65 \mathrm{ppm}$ had disappeared, and one double doublet peak at $\delta$ $3.56 \mathrm{ppm}$ had changed to a broad doublet at $\delta 3.54 \mathrm{ppm}$. These results confirmed that the $\mathrm{H} 1$ proS of $1 \mathrm{a}$ was selectively replaced with a deuterium. In the spectrum of $\mathbf{1 b}$, one proton signal at $\delta 3.56 \mathrm{ppm}$ disappeared, and double doublet peaks centered at $\delta 3.65 \mathrm{ppm}$ changed to the broad doublet at $\delta 3.64 \mathrm{ppm}$. These results also confirmed that the $\mathrm{HI}$ proR was selectively replaced by a deuterium. The partially relaxed ${ }^{1} \mathrm{H}-\mathrm{NMR}$ spectra $(180-t-90 \mathrm{pu}-$ lse with internal times $(t)=1300 \mathrm{msec}$ ) were successfully applied to separate the signals of a methin proton at $\mathrm{C}-1$ from one of the overlapping $\mathrm{H}-3$ signals, and thereby to characterize more precisely the two isomers $\mathbf{1 a}$ and $\mathbf{1 b}$. In the same way, the two isomeric tripalmitins derived from $\mathbf{1 a}$ and $\mathbf{1 b}$ were also characterized (Fig. 2).

c) $(1 R)-\left[1-^{2} \mathrm{H}\right]-s n-$ Glycerol (1b)
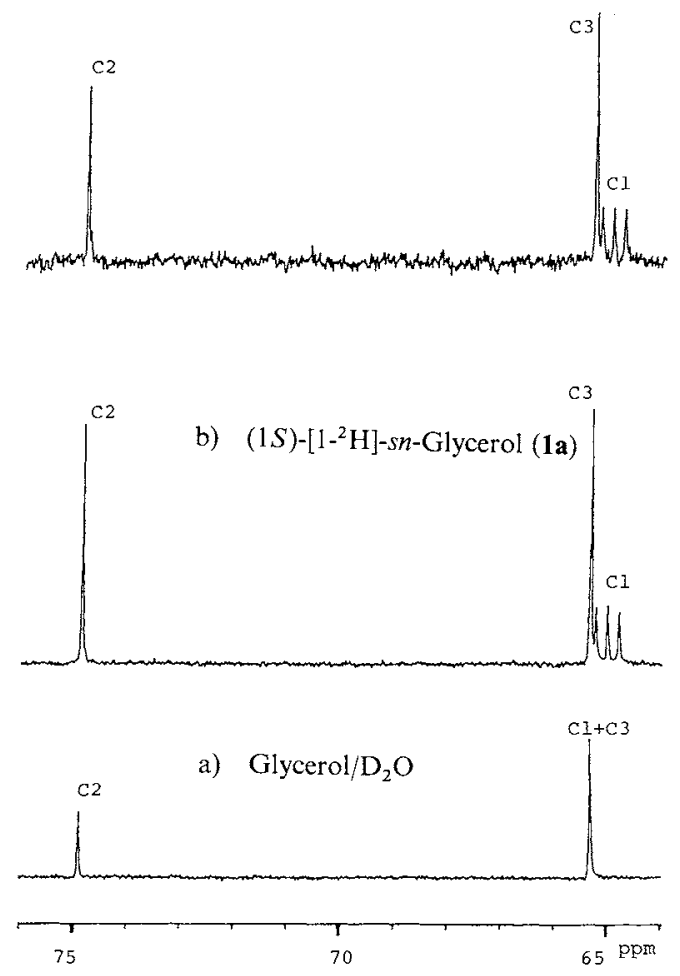

Fig. 3. $100 \mathrm{MHz}{ }^{13} \mathrm{C}-\mathrm{NMR}$ Spectra (Complete Proton Decoupling) of Glycerol, $\mathbf{1 a}$ and $\mathbf{1 b}$ in $\mathrm{D}_{2} \mathrm{O}$.
In Fig. 3, the ${ }^{13} \mathrm{C}-\mathrm{NMR}$ spectra of $\mathbf{1 a}, \mathbf{1 b}$ and glycerol in $\mathrm{D}_{2} \mathrm{O}$ are compared. A significant change in the intensity of the peak $(\mathrm{C}-1$ and $\mathrm{C}-3)$ at $\delta 65.3 \mathrm{ppm}$ and the appearance of new triplet signals at $\delta 65.0 \mathrm{ppm}$ confirmed that the $\mathrm{C}-1$ position in $\mathbf{1 a}$ and $\mathbf{1 b}$ was monodeuteriated. The chemical shifts of C-1, C-2 and $\mathrm{C}-3$ showed little difference between 1a and $\mathbf{1 b}$ to characterize their stereochemistry (Table I), and similar results were obtained for the tripalmitins (Fig. 4).

The isotope shifts in the ${ }^{13} \mathrm{C}$-NMR spectra of $\mathbf{1 a}, \mathbf{1 b}$ and the tripalmitins are also summarized in Table 1. The isotope shift was observed in the order of the magnitude of as C$1>\mathrm{C}-2>\mathrm{C}-3$ for $\mathbf{1 a}$ and $\mathbf{1 b}$, as well as for the two deuteriated tripalmitins. The isotope shift has been suggested to change due to the spacial distance from the deuterium or to the linearity with the $\mathrm{C}-{ }^{2} \mathrm{H}$ axis. ${ }^{12,13)} \mathrm{We}$ could, therefore

Table I. ${ }^{13}$ C-NMR IsOTOPE SHIFTS IN $s n$-GLyCEROLS and Tripalmitins Chirally Deuterated AT THE C-1 POSITION

\begin{tabular}{|c|c|c|c|c|}
\hline \multirow[b]{2}{*}{ Compound } & \multirow[b]{2}{*}{ Solvent } & \multicolumn{3}{|c|}{$\delta$ Chemical shift $(\mathrm{ppm})^{a, b}$} \\
\hline & & $\begin{array}{c}\mathrm{Cl} \\
(\Delta \mathrm{C} 1)\end{array}$ & $\begin{array}{c}C 2 \\
(\Delta \mathrm{C} 2)\end{array}$ & $\begin{array}{c}\mathrm{C} 3 \\
(\Delta \mathrm{C} 3)^{c}\end{array}$ \\
\hline Glycerol & $\mathrm{D}_{2} \mathrm{O}$ & $\begin{array}{l}65.34 \\
(0.0)\end{array}$ & $\begin{array}{l}74.92 \\
(0.0)\end{array}$ & $\begin{array}{l}65.34 \\
(0.0)\end{array}$ \\
\hline $\begin{array}{l}(1 S)-\left[1-{ }^{2} \mathrm{H}\right] \\
\text { Glycerol }\end{array}$ & $\mathrm{D}_{2} \mathrm{O}$ & $\begin{array}{c}64.99 \\
(-0.35)\end{array}$ & $\begin{array}{c}74.85 \\
(-0.07)\end{array}$ & $\begin{array}{c}65.31 \\
(-0.03)\end{array}$ \\
\hline$(1 R)-\left[1-{ }^{2} \mathrm{H}\right]$ & $\mathrm{D}_{2} \mathrm{O}$ & $\begin{array}{r}64.99 \\
(-035)\end{array}$ & $\begin{array}{r}74.85 \\
(-007)\end{array}$ & $\begin{array}{r}65.33 \\
(-001)\end{array}$ \\
\hline Tripalmitin & $\mathrm{CDCl}_{3}$ & $\begin{array}{l}62.08 \\
(0.0)\end{array}$ & $\begin{array}{c}68.83 \\
(0.0)\end{array}$ & $\begin{array}{l}62.08 \\
(0.0)\end{array}$ \\
\hline$(1 S)-\left[1-{ }^{2} \mathrm{H}\right]$ & $\mathrm{CDCl}_{3}$ & 61.79 & 68.78 & 62.07 \\
\hline Tripalmitin & & $(-0.29)$ & $(-0.05)$ & $(-0.01)$ \\
\hline$(1 R)-\left[1-{ }^{2} \mathrm{H}\right]$ & $\mathrm{CDCl}_{3}$ & 61.79 & 68.78 & 62.07 \\
\hline Tripalmitin & & $(-0.29)$ & $(-0.05)$ & $(-0.01)$ \\
\hline
\end{tabular}

a Measured at $100 \mathrm{MHz}$ in the completely ${ }^{1} \mathrm{H}$ decoupled mode with resolution at $\pm 0.015 \mathrm{ppm}$.

b Referred to the internal 3-(trimethylsilyl)propanesulfonic acid sodium salt $(0.000 \mathrm{ppm})$ for the glycerols and to $\mathrm{CDCl}_{3}(77.000 \mathrm{ppm})$ for the tripalmitins.

c Difference in the chemical shifts between the deuteriated and non-deuteriated analogues.

Ex. $\triangle \mathrm{Cl}=\mathrm{Cl}$ (deuteriated derivative)- $\mathrm{Cl}$ (nondeuteriated analogue). 


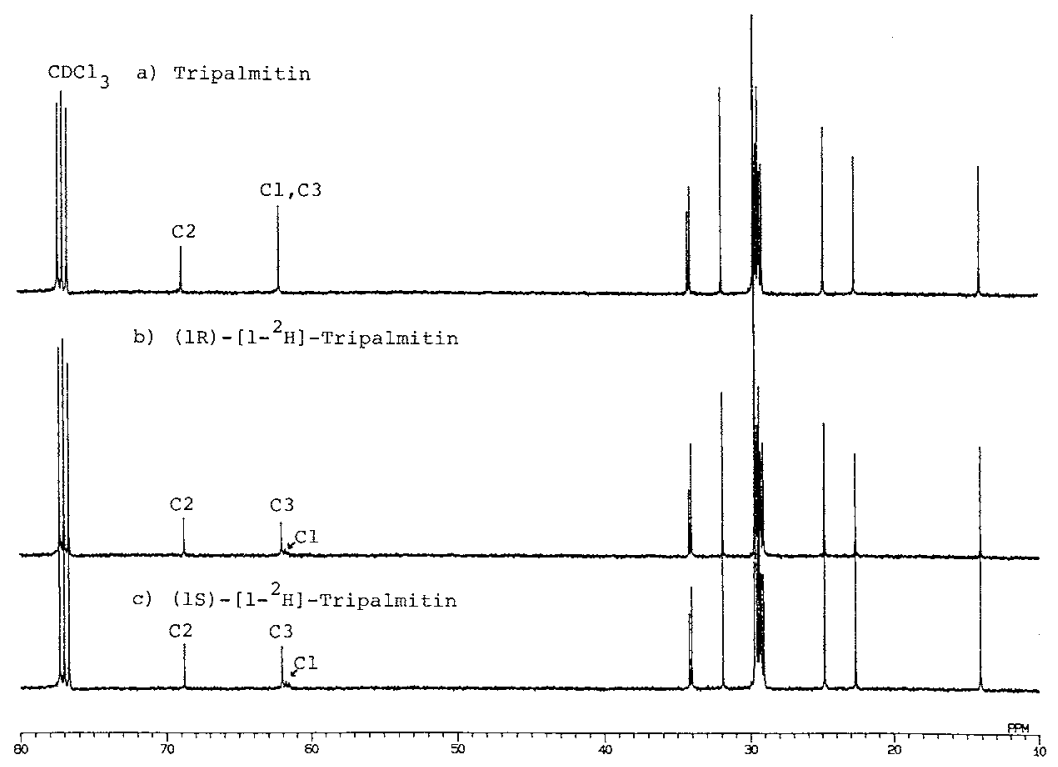

Fig. 4. $100 \mathrm{MHz}{ }^{13} \mathrm{C}-\mathrm{NMR}$ Spectra (Complete Proton Decoupling) of Tripalmitin and Its (1S)- and (1R)Deuteriated Analogues in $\mathrm{CDCl}_{3}$.

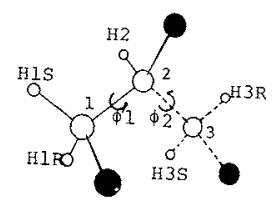

$g g(\phi 1)$

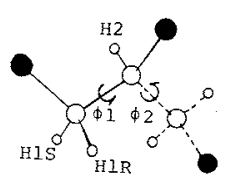

$g t(\phi 1)$

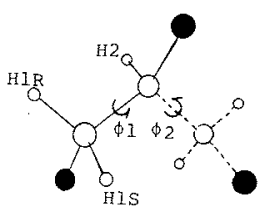

$\operatorname{tg}(\phi 1)$

Fig. 5. Three Rotamers about the $\mathrm{C} 1-\mathrm{C} 2(\phi 1)$ Bond, $g g$, $g t$ and $t g$.

$\mathrm{gg}$ calls for a conformation where the $\mathrm{Cl}-\mathrm{O} 1$ axis is gauche to both of the $\mathrm{C} 2-\mathrm{O} 2$ and $\mathrm{C} 2-\mathrm{C} 3$ axes, $g t$ calls for a conformation where the $\mathrm{C} 1-\mathrm{O} 1$ axis is gauche to the $\mathrm{C} 2-\mathrm{O} 2$ and trans to the $\mathrm{C} 2-\mathrm{C} 3$, and $t g$ calls for a conformation where the $\mathrm{C} 1-\mathrm{O} 1$ axis is trans to the $\mathrm{C} 2-\mathrm{O} 2$ and gauche to the $\mathrm{C} 2-\mathrm{C} 3$ axis.

Here, the conformation about the $\mathrm{C} 2-\mathrm{C} 3$ bond $(\phi 2)$ is not specified.

have expected some difference in the deuterium shift between $\mathbf{1 a}$ and $\mathbf{1 b}$ or the two deuteriated tripalmitins. In our experiments, however, the isotope shift for the ${ }^{13} \mathrm{C}$ signals showed little difference between the two sets of diastereomers. This may be ascribed to rotational averaging due to rapid rotation along the $\mathrm{C} 1-\mathrm{C} 2(\phi 1, \mathrm{Fig} .5)$ or $\mathrm{C} 2-\mathrm{C} 3$ bond $(\phi 2)$ in solution. c) Complete assignments of the prochiral protons at $\mathrm{Cl}$ and $\mathrm{C} 3$ of sn-glycerides and conformational analyses

The ${ }^{1} \mathrm{H}-\mathrm{NMR}$ spectra shown in Figs. 1 and 2 enabled us to assign all four prochiral protons at $\mathrm{C} 1$ and $\mathrm{C} 3$ of the glycerides, which has long been an unresolved problem in the conformational study of glycerolipids. ${ }^{3 \sim 7)}$ This success is significant, because the two protons at $\mathrm{C} 1$ (or $\mathrm{C} 3$ ) were magnetically unequivalent to give separate signals, whose NMR parameters (vicinal coupling constants $\left({ }^{3} J_{\mathrm{H}, \mathrm{H}}\right)$, chem- 
Table II. $400 \mathrm{MHz}{ }^{1} \mathrm{H}-\mathrm{NMR}$ Data of $s n$-Glycerol and Its Tri- $O$-ACYlates

\begin{tabular}{|c|c|c|c|c|c|c|c|c|}
\hline \multirow{2}{*}{\multicolumn{2}{|c|}{ Compound }} & \multirow{2}{*}{$\begin{array}{c}\text { Chemical } \\
\text { shift }(p p m)^{a}\end{array}$} & \multirow{2}{*}{ Assingment } & \multirow{2}{*}{$\begin{array}{c}{ }^{2} J^{b} \\
(\mathrm{~Hz})\end{array}$} & \multirow{2}{*}{$\begin{array}{c}{ }^{3} J \\
(\mathrm{~Hz})\end{array}$} & \multicolumn{3}{|c|}{ Population $(\%)$} \\
\hline & & & & & & $g g$ & $g t$ & $\operatorname{tg}$ \\
\hline \multirow{12}{*}{ 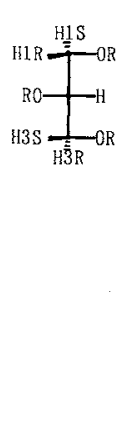 } & $\mathrm{R}=$ & 3.652 & $\mathrm{H} 1 S, \mathrm{H} 3 R$ & 11.7 & 4.2 & \multirow[t]{3}{*}{33} & \multirow[t]{3}{*}{52} & \multirow[t]{3}{*}{15} \\
\hline & $\mathrm{H}$ & 3.557 & $\mathrm{H} 1 \mathrm{R}, \mathrm{H} 3 \mathrm{~S}$ & \multirow[t]{2}{*}{11.7} & \multirow[t]{2}{*}{6.6} & & & \\
\hline & $\left(\mathrm{D}_{2} \mathrm{O}\right)$ & 3.780 & $\mathrm{H} 2$ & & & & & \\
\hline & Pal & 4.294 & $\mathrm{H} 1 S, \mathrm{H} 3 \mathrm{R}$ & 11.7 & 4.4 & \multirow[t]{3}{*}{37} & \multirow[t]{3}{*}{45} & \multirow[t]{3}{*}{18} \\
\hline & $\left(\mathrm{CDCl}_{3}\right)$ & 4.145 & $\mathrm{H} 1 R, \mathrm{H} 3 S$ & \multirow[t]{2}{*}{11.7} & \multirow[t]{2}{*}{6.0} & & & \\
\hline & & 5.267 & $\mathrm{H} 2$ & & & & & \\
\hline & $\mathrm{Ac}$ & 4.299 & $\mathrm{H} I S, \mathrm{H} 3 R$ & 12.1 & 4.4 & \multirow[t]{3}{*}{39} & \multirow[t]{3}{*}{43} & \multirow[t]{3}{*}{18} \\
\hline & $\left(\mathrm{CDCl}_{3}\right)$ & 4.162 & $\mathrm{H} 1 R, \mathrm{H} 3 S$ & \multirow[t]{2}{*}{12.1} & \multirow[t]{2}{*}{5.9} & & & \\
\hline & & 5.253 & $\mathrm{H} 2$ & & & & & \\
\hline & $\mathrm{Bz}$ & 4.755 & $\mathrm{H} 1 S, \mathrm{H} 3 R$ & 12.1 & 4.4 & \multirow[t]{3}{*}{39} & \multirow[t]{3}{*}{43} & \multirow[t]{3}{*}{18} \\
\hline & $\left(\mathrm{CDCl}_{3}\right)$ & 4.686 & $\mathrm{H} 1 R, \mathrm{H} 3 S$ & 12.1 & 5.8 & & & \\
\hline & & 5.834 & $\mathrm{H} 2$ & & & & & \\
\hline
\end{tabular}

a 3-(Trimethylsilyl)-propanesulfonic acid sodium salt as internal standard $(0.000 \mathrm{ppm})$ for glycerol $(\mathrm{R}=\mathrm{H})$, and tetramethylsilane (TMS) as the internal standard $(0.000 \mathrm{ppm})$ for its tri- $O$-acylates (Ac, Bz, Pal).

$b$ Observed first order couplings $\pm 0.2 \mathrm{~Hz}$.

c Calculated from the following equations based on the Karplus equation of Haasnoot et al. (refs. 14, 19 and 20).

$$
\begin{aligned}
2.8 g g+3.1 g t+10.7 t g & =\mathrm{JH} 1 S, \mathrm{H} 2 \\
0.9 g g+10.7 g t+5.0 t g & =\mathrm{JH} 1 R, \mathrm{H} 2 \\
g g+g t+\quad t g & =1
\end{aligned}
$$

ical shifts and relaxation rates) would provide key information for the conformation in solution. ${ }^{4 \sim 7)}$ The complete assignment of the four prochiral protons ( $\mathrm{H} 1$ proR, $\mathrm{H} 1 \mathrm{proS}$, $\mathrm{H} 3$ pro $R$ and $\mathrm{H} 3$ proS ) of $s n$-glycerol and tri-Oacylated glycerides are summarized in Table II, where the rotameric distribution of the three staggered conformers, namely $g t, g g$ and $\operatorname{tg}$ (Fig. 5) calculated from the vicinal coupling constants with $\mathrm{H} 2{ }^{6,7)}$ are also given. The significant points could be summarized as follows: (1) $\mathrm{H} 1$ pro $\mathrm{R}$ (or $\mathrm{H} 3$ proS) showed higher field shifts and larger coupling constants with $\mathrm{H}-2$ than did $\mathrm{H} 1$ proS (or H3proR), and (2) the two gauche conformers $g g$ and $g t$ predominated in which $g t$ was more favored. The preference of the two gauche conformers ( $g g$ and $g t$ ) agreed with the the results for phospholipids by Hauser et al ${ }^{6,7)}$ as consistent with the gauche effect ${ }^{15,16)}$ which has been well accepted for carbohydrate molecules with acyclic C5-C6 bonds. ${ }^{17,18)}$ These results will become an important basis for further conformational analyses of glycerolipids by NMR spectroscopy.

\section{Experimental}

IR spectra were recorded on a Jasco A-202 spectrometer in liquid film form on a $\mathrm{KBr}$ plate. ${ }^{1} \mathrm{H}$-NMR spectra were recorded with a JEOL FX-100 spectrometer, and optical rotation was measured on a Jasco J-20 spectrometer at a $589 \mathrm{~nm}$ wavelength. Kiesel gel $60 \mathrm{GF}_{254}$ (Merck) was used for both analytical and preparative TLC.

(1S)- $\left(1-{ }^{2} H\right)-1,2-O-(2-H y d r o x y e t h y l i d e n e)-s n$-glycerol (3). A mixture of $(6 S)-\left(6^{2} \mathrm{H}\right)-1,6$-anhydro- $\beta$-D-galactopyranose $\left(2,{ }^{10)} 500 \mathrm{mg}\right)$ and $\mathrm{NaIO}_{4}(1.6 \mathrm{~g})$ in water $(50$ $\mathrm{ml}$ ) was stirred for $1 \mathrm{hr}$ at room temperature, neutralized with $0.1 \mathrm{~m}$ barium hydroxide solution, and then filtered with a pad of celite. The filtrate was poured into an $\mathrm{NaBH}_{4}$ (300 mg)-ethanol $(10 \mathrm{ml})$ mixture, and the solution was stirred for $3 \mathrm{hr}$. After the excess $\mathrm{NaBH}_{4}$ had been decomposed with acetic acid, the mixture was concentrated to dryness. The residue was treated with a pyridine $(50 \mathrm{ml})$-acetic anhydride $(10 \mathrm{ml})$ mixture for $12 \mathrm{hr}$. The solution was repeatedly concentrated in vacuo with an ethanol-toluene mixture, and the residue was chromatographed on $\mathrm{SiO}_{2}$ in $30: 1$ toluene-ethyl acetate to give a syrupy $(1 S)-\left(1-{ }^{2} \mathrm{H}\right)-1,2-O$-(2-acetoxyethylidene)$3-O$-acetyl-sn-glycerol $(500 \mathrm{mg}, 77 \%) .[\alpha]_{\mathrm{D}}-5.5^{\circ}(0.6$, $\left.\mathrm{CHCl}_{3}\right) .{ }^{1} \mathrm{H}-\mathrm{NMR} \quad\left(\mathrm{CDCl}_{3}, \quad \mathrm{TMS}\right): 2.10 \quad(3 \mathrm{H}, \mathrm{s}$, $\left.-\mathrm{OCOCH}_{3}\right), 2.11\left(3 \mathrm{H}, \mathrm{s}, \mathrm{OCOCH}_{3}\right), 3.82(1 \mathrm{H}$, broad d, $4.9 \mathrm{~Hz}, \mathrm{H}-\mathrm{l}), 4.1 \sim 4.3\left(4 \mathrm{H}, \mathrm{m}, \mathrm{H}-2 \mathrm{a}^{\prime}+\mathrm{H}-2 \mathrm{~b}^{\prime}+\mathrm{H}-3 \mathrm{a}^{\prime}+\mathrm{H}-\right.$ $\left.3 b^{\prime}\right), 4.2 \sim 4.44(1 \mathrm{H}, \mathrm{m}, \mathrm{H}-2), 5.16(1 \mathrm{H}, \mathrm{t}, 3.8 \mathrm{~Hz}, \mathrm{H}-1)$. IR $v \mathrm{~cm}^{-1}: 2920,2850,1730,1430,1362,1220,1140,1040$, 
$930,860,600$.

A mixture of sodium (ca. $5 \mathrm{mg}$ ) and this syrup (100 mg) in dry methanol $(10 \mathrm{ml})$ was stirred for $3 \mathrm{hr}$, neutralized with Amberlite IR-120 resin ( $\mathrm{H}^{+}$form), filtered to remove the resin and concentrated to give a syrupy $3(60 \mathrm{mg}, 98 \%)$. $[\alpha]_{\mathrm{D}}+3.2^{\circ}(\mathrm{c} 1.9, \mathrm{MeOH})$. IR $v \mathrm{~cm}^{-1}: 3360(\mathrm{OH}), 1620$, $1140,1040 .{ }^{1} \mathrm{H}-\mathrm{NMR}\left(\mathrm{D}_{2} \mathrm{O}, \mathrm{DSS}\right): 3.5 \sim 3.8(4 \mathrm{H}, \mathrm{H}-$ $\left.2 \mathrm{a}^{\prime}+\mathrm{H}-2 \mathrm{~b}^{\prime}+\mathrm{H}-3 \mathrm{a}+\mathrm{H}-3 \mathrm{~b}\right), 3.82(1 \mathrm{H}$, broad $\mathrm{d}, 5.6 \mathrm{~Hz}$, $\mathrm{H} 1$ proR $), 4.30(1 \mathrm{H}, \mathrm{m}, \mathrm{H}-2), 5.06\left(1 \mathrm{H}, \mathrm{t}, 2.9 \mathrm{~Hz}, \mathrm{H}-1^{\prime}\right)$.

(1S)-(1-2 H)-sn-Glycerol (1a). Crude 3 dissolved in $60 \%$ trifluoroacetic acid (TFA) was kept at $60^{\circ} \mathrm{C}$ for $12 \mathrm{hr}$ and concentrated in vacuo. The syrupy residue was treated with a pyridine $(2 \mathrm{ml})$-acetic anhydride $(0.5 \mathrm{ml})$ mixture for $12 \mathrm{hr}$. The mixture vas concentrated, and chromatographed on $\mathrm{SiO}_{2}$ in benzene-ethyl acetate $(3: 1)$ to give a syrupy $(1 S)-\left(1-{ }^{2} \mathrm{H}\right)$-tri- $O$-acetyl-sn-glyceride. Deacetylation of this compound in cat. $\mathrm{NaOMe}-\mathrm{MeOH}$ in the same way as that for the preparation of 3 gave 1 a $(30$ $\mathrm{mg}, 80 \%$ yield from 2 ).

(1S)-(1- $\left.{ }^{2} \mathrm{H}\right)-1,2-O-(2-O-B e n z y l o x y e t h y l i d e n e)-3-O-$ benzyl-sn-glycerol (4). A mixture of $3(150 \mathrm{mg}), \mathrm{NaH}$ $(110 \mathrm{mg})$ and benzyl bromide $(470 \mathrm{mg})$ in dimethylformamide $(10 \mathrm{ml})$ was stirred for $2 \mathrm{hr}$. The excess $\mathrm{NaH}$ was decomposed with small amount of methanol, and the solution was concentrated in vacuo. The residual syrup was diluted in $20 \mathrm{ml}$ of $\mathrm{CHCl}_{3}$, washed with water, dried over $\mathrm{MgSO}_{4}$, and concentrated. The residual syrup was chromatographed on $\mathrm{SiO}_{2}$ in $n$-hexane-benzene-ethyl acetate $(10: 1: 1)$ to give $4(320 \mathrm{mg}, 91 \%) \cdot[\alpha]_{\mathrm{D}}+15.4^{\circ}$ (c 0.5 , $\mathrm{CHCl}_{3}$ ). IR v cm${ }^{-1}: 2850,1490,1445,1360,1244,1204$, $1100,738,695,602 .{ }^{1} \mathrm{H}-\mathrm{NMR}\left(\mathrm{CDCl}_{3}, \mathrm{TMS}\right): 3.3 \sim 3.7$ $\left(4 \mathrm{H}, \mathrm{m}, \mathrm{H}-3 \mathrm{a}+\mathrm{H}-3 \mathrm{~b}+\mathrm{H}-2 \mathrm{a}^{\prime}+\mathrm{H}-2 \mathrm{~b}^{\prime}\right), 3.82(\mathrm{lH}$, broad d, $5.8 \mathrm{~Hz}, \mathrm{H}-1 \mathrm{~S}), 4.25(1 \mathrm{H}, \mathrm{m}, \mathrm{H}-2), 4.54\left(2 \mathrm{H}, \mathrm{s},-\mathrm{CH}_{2}-\mathrm{Ph}\right)$, $4.59\left(2 \mathrm{H}, \mathrm{s},-\mathrm{CH}_{2} \mathrm{Ph}\right), 5.10(1 \mathrm{H}, \mathrm{t}, 3.9 \mathrm{~Hz})$.

(IS)-(I-2 H)-3-O-Benzyl-sn-glycerol (5). A solution of 4 $\left(200 \mathrm{mg}\right.$ ) in $60 \%$ TFA was kept at $60 \sim 65^{\circ} \mathrm{C}$ for $24 \mathrm{hr}$ and concentrated in vacuo. The residual syrup was chromatographed on $\mathrm{SiO}_{2}$ in chloroform-MeOH $(100: 1)$ to afford syrupy $5(80 \mathrm{mg}, 68 \%) \cdot[\alpha]_{\mathrm{D}}+16^{\circ}(c 0.16, \mathrm{MeOH}) .{ }^{1} \mathrm{H}-$ NMR $\left(\mathrm{D}_{2} \mathrm{O}, \mathrm{DSS}\right): 3.3 \sim 3.8(3 \mathrm{H}, \mathrm{Hl}$ proR $+\mathrm{H}-3 \mathrm{a}+\mathrm{H}-$ 3b), $3.89(1 \mathrm{H}, \mathrm{m}, \mathrm{H}-2), 4.52\left(2 \mathrm{H}, \mathrm{s}, \mathrm{CH}_{2}-\mathrm{Ph}\right), 4.85(2 \mathrm{H}, \mathrm{s}$, $2 \times \mathrm{DOH}), 7.36\left(5 \mathrm{H}, \mathrm{s},-\mathrm{C}_{6} \mathrm{H}_{5}\right)$.

(IS)- $\left(I-{ }^{2} H\right)-I-O-{ }^{t} B u t y l d i m e t h y l$ silyl-3-O-benzyl-snglycerol (6). To a mixture of 5 (120 $\mathrm{mg})$, triethylamine $(120 \mathrm{mg})$ and $4-(N, N$-dimethylamino)pyridine $(20 \mathrm{mg})$ in $\mathrm{CH}_{2} \mathrm{Cl}_{2}$ (10 ml) was added 'butyldimethylsilylchloride $(240 \mathrm{mg})$. The mixture was stirred at room temperature for $6 \mathrm{hr}$, washed with water and dried over $\mathrm{MgSO}_{4}$. The solution was concentrated to give a syrupy residue, which was chromatographed on $\mathrm{SiO}_{2}$ in $n$-hexane-ethyl acetate $(50: 1)$ to afford $6(167 \mathrm{mg}, 85 \%),[\alpha]_{\mathrm{D}}+11.5^{\circ}$ (c 0.3 , $\left.\mathrm{CHCl}_{3}\right)$. IR $v \mathrm{~cm}^{-1}: 3450,2920,2850,1460,1250,1090$, $835,772,730,695 .{ }^{1} \mathrm{H}-\mathrm{NMR}\left(\mathrm{CDCl}_{3}, \mathrm{TMS}\right): 0.04(6 \mathrm{H}, \mathrm{s}$,
$\left.-\mathrm{Si}\left(\mathrm{CH}_{3}\right)_{2}\right), 0.86\left(9 \mathrm{H}, \mathrm{s},-\mathrm{Si}{ }^{t} \mathrm{Bu}\right), 2.44(1 \mathrm{H}, \mathrm{d}, 4.9 \mathrm{~Hz}, \mathrm{OH}-$ 2), $3.5 \sim 3.8(3 \mathrm{H}, \mathrm{H} 1$ proR $+\mathrm{H}-3 \mathrm{a}+\mathrm{H}-3 \mathrm{~b}), 3.8(1 \mathrm{H}, \mathrm{m}, \mathrm{H}-$ 2), $4.52\left(2 \mathrm{H}, \mathrm{s},-\mathrm{CH}_{2} \mathrm{Ph}\right), 7.30\left(5 \mathrm{H}, \mathrm{s},-\mathrm{C}_{6} \mathrm{H}_{5}\right)$.

$(I S)-\left(1-{ }^{2} H\right)-2,3-d i-O-B e n z y l-s n$-glycerol (8). A mixture of $6(100 \mathrm{mg}), \mathrm{NaH}(20 \mathrm{mg})$ and benzylbromide $(100 \mathrm{mg})$ in dimethylformamide $(10 \mathrm{ml})$ was stirred for $3 \mathrm{hr}$ at room temperature. After the excess $\mathrm{NaH}$ had been decomposed with methanol, the mixture was diluted with $\mathrm{CHCl}_{3}$ $\left(30 \mathrm{ml}\right.$ ), washed with water, dried over $\mathrm{MgSO}_{4}$ and concentrated in vacuo. The residual syrup was dissolved in $1 \mathrm{M}$ $n-\mathrm{Bu}_{4} \mathrm{NF}$ in a tetrahydrofuran solution $(2 \mathrm{ml})$, and the mixture was refluxed for $3 \mathrm{hr}$. The solution was diluted with $50 \mathrm{ml}$ of ethyl acetate, washed with a sat. $\mathrm{NaCl}$ aqueous solution, dried over $\mathrm{Na}_{2} \mathrm{SO}_{4}$ and concentrated in vacuo. The residual syrup was chromatographed on $\mathrm{SiO}_{2}$ in benzene-ethyl acetate $(5: 1)$ to give a syrupy $8(80 \mathrm{mg}$, $87 \%) \cdot[\alpha]_{\mathrm{D}}+21.8^{\circ}\left(c 0.22, \mathrm{CHCl}_{3}\right)$. IR $v \mathrm{~cm}^{-1}: 3400(\mathrm{OH})$, $2920,2850(\mathrm{CH}), 738(\mathrm{Bn}), 698(\mathrm{Bn})$.

(IR)-(1-2 H)-1-O-Benzoyl-2,3-di-O-benzyl-sn-glycerol (10). To a stirred solution of $8(70 \mathrm{mg})$ in pyridine $(15 \mathrm{ml})$ was added dropwise methanesulfonyl chloride $(0.1 \mathrm{ml})$. The mixture was stirred for $0.5 \mathrm{hr}$ and poured into an icewater mixture $(10 \mathrm{ml})$. The mixture was extracted with chloroform $(3 \times 10 \mathrm{ml})$, before the combined extract was washed with water, sat. $\mathrm{NaHCO}_{3}$ and water, and dried over $\mathrm{MgSO}_{4}$. Analytical TLC (silica gel, ethyl acetatebenzene $=1: 10$ ) for the dried solution showed the complete disappearance of $\mathbf{8}(R f=0.1)$ and the appearance of new single spot of a 1-O-mesylated compound (9, $R f=0.3$ ). Concentration of the solution gave a syrupy residue, which was purified through a short silica gel column in benzene-ethyl acetate $(20: 1)$. A mixture of 9 and sodium benzoate $(100 \mathrm{mg})$ in dimethylformamide $(10 \mathrm{ml})$ was stirred at $120^{\circ} \mathrm{C}$ for $6 \mathrm{hr}$. After the mixture had been cooled to room temperature, a sat. $\mathrm{NaCl}$ aqueous solution $(20 \mathrm{ml})$ was added, and the solution was extracted with ethyl acetate $(10 \mathrm{ml} \times 3)$. The combined extract was washed with a sat. $\mathrm{NaCl}$ aqueous solution, dried over $\mathrm{Na}_{2} \mathrm{SO}_{4}$ and concentrated. The residual syrup was chromatographed on a silica gel column in $n$-hexane-ethyl aceate $(10: 1)$ to afford a syrupy $\mathbf{1 0}(78 \mathrm{mg}, 80 \%$ from $\mathbf{1 0})$. $[\alpha]_{\mathrm{D}}-16.7^{\circ}(c 0.1, \mathrm{MeOH}) . \mathrm{IR} v \mathrm{~cm}^{-1}: 1720(-\mathrm{O}-\mathrm{CO}-\mathrm{Ph})$, $1600,1450,1270,1100,735,710,695 .{ }^{1} \mathrm{H}-\mathrm{NMR}\left(\mathrm{CDCl}_{3}\right.$, TMS): $3.66\left(2 \mathrm{H}, \mathrm{H}-3+\mathrm{H}-3^{\prime}\right),\left(2 \mathrm{H}, \mathrm{H}-3+\mathrm{H}-3^{\prime}\right), 4.00(1 \mathrm{H}$, $\mathrm{m}, \mathrm{H}-2), 4.51(\mathrm{HH}, \mathrm{d}, \mathrm{H}-\mathrm{lS}), 4.57\left(2 \mathrm{H}, \mathrm{s},-\mathrm{CH}_{2}-\mathrm{Ph}\right), 4.72$ $\left(2 \mathrm{H}, \mathrm{s},-\mathrm{CH}_{2}-\mathrm{Ph}\right), 7.3 \sim 7.6(13 \mathrm{H}, \mathrm{m}, 2 \times \mathrm{Ph}(5 \mathrm{H})$ and benzoyl protons at meta $(2 \mathrm{H})$ and para $(1 \mathrm{H})$ positions), $8.0 \mathrm{I}(2 \mathrm{H}, \mathrm{dd}$, benzoyl protons at ortho positions $(2 \mathrm{H}))$.

$(1 R)-\left(1-{ }^{2} H\right)-s n-G l y c e r o l$ (1b). A mixture of $10(70 \mathrm{mg})$ and $\mathrm{Na}(\mathrm{ca} .2 \mathrm{mg})$ in $\mathrm{MeOH}(10 \mathrm{ml})$ was heated at $55^{\circ} \mathrm{C}$ for $2 \mathrm{hr}$, neutralized with Amberite IR-120 resin ( $\mathrm{H}^{+}$form) and concentrated. The residue was chromatographed on $\mathrm{SiO}_{2}$ in $n$-hexane-ethyl acetate $(10: 1)$ to give a syrupy (1R)-isomer of $8(48 \mathrm{mg}, 95 \%)$. The syrup ( $48 \mathrm{mg}$ ) was dissolved in $\mathrm{MeOH}$ and hydrogenated with Pd-black 
(100 mg) at room temperature. The catalyst was removed by filtration, and the filtrate was evaporated to dryness to afford a syrupy $\mathbf{1 b}(11 \mathrm{mg}, 72 \%$ from $\mathbf{1 0})$.

\section{References and Notes}

1) For recent biosynthetic studies on $O$-alkylated glycerols, see Refs. la $\sim 1$ c. 1a) S. J. Friedberg, S. T. Weintrabe, D. Peterson and N. Satsangi, Biochem. Biophys. Res. Commun., 145, 1177 (1987), and their related works therein. 1b) A. J. Brown and F. Synder, J. Biol. Chem., 258, 4184 (1983). 1c) K. Kakinuma, M. Yamagishi, Y. Fujimoto, N. Ikekawa and T. Oshima, J. Am. Chem. Soc., 110, 4861 (1988).

2) C. A. Townsend and S. Mao, J. Chem. Soc., Chem. Commun., 1987, 86.

3) Recently, ${ }^{4,5\}}$ chirally deuterated glycerols have been successfully employed for ${ }^{2} \mathrm{H}-\mathrm{NMR}$ studies on the conformation of glycolipid analogues.

4) H. C. Jarrell, P. A. Jovall, J. B. Giziewicz, L. A. Turner and I. C. P. Smith, Biochemistry, 26, 1805 (1987).

5) P. Ram and J. H. Prestegard, J. Am. Chem. Soc., 110, 2383 (1988).

6) H. Hauser, W. Guyer, B. Levine, P. Skarabal and R. J. P. Williams, Biochim. Biophys. Acta, 508, 450 (1978).

7) H. Hauser, I. Pascher and S. Sundell, Biochemistry, 27, 9166 (1988).
8) Preliminarily communicated in $H$. Uzawa, $Y$. Nishida, S. Hanada, H. Ohrui and H. Meguro, $J$. Chem. Soc., Chem. Commun., 1989, 862.

9) H. Ohrui, H. Horiki, H. Kishi and H. Meguro, Agric. Biol. Chem., 47, 1750 (1983).

10) H. Ohrui, Y. Nishida and H. Meguro, Agric. Biol. Chem., 48, 1049 (1984).

11) H. Hori, T. Nakajima, Y. Nishida, H. Ohrui and $H$. Meguro, J. Carbohydrate Chem., 5, 585 (1986).

12) R. Aydin, J. R. Wesener, H. Gunther, R. L. Santillan, M. E. Garibay and P. J. Nathan, J. Org. Chem., 49, 3845 (1984).

13) K. L. Servis and R. L. Domenick, J. Org. Chem., 108, 2211 (1986).

14) L. H. Koole, H. D. Boer, J. W. Haan, C. A. G. Haasnoot, P. Dael and H. M. Buck, J. Chem. Soc., Chem. Commun., 1986, 362.

15) S. Wolfe, Acc. Chem. Res., 5, 102 (1972).

16) M. Duin, J. M. A. Baas and B. Graaf, J. Org. Chem., 51, 1298 (1986).

17) H. Ohrui, Y. Nishida, H. Higuchi, H. Hori and $H$. Meguro, Can. J. Chem., 65, 1145 (1987).

18) Y. Nishida, H. Hori, H. Ohrui, H. Meguro, J. Uzawa, D. Reimer, V. Sinnwell and H. Paulsen, Tetrahedron Lett., 29, 4461 (1988).

19) C. A. G. Haasnoot, F. A. A. Leeuw and C. Altona, Tetrahedron, 36, 2783 (1980).

20) Y. Nishida, H. Hori, H. Ohrui and H. Meguro, $J$. Carbohydrate Chem., 7, 239 (1988). 